\title{
Analysis of the tensile strength on the healing of the abdominal wall of rats treated with infliximab ${ }^{1}$
}

\author{
Análise da força tênsil na cicatrização da parede abdominal de ratos tratados com infliximabe
}

\author{
João Vieira LopesI, Luís Alberto Mendonça de Freitas", Ravi Dias Marques ${ }^{\mathrm{III}}$, Anamélia Lorenzetti Bocca ${ }^{\mathrm{IV}}$, João Batista de \\ Sousa $^{\mathrm{IV}}$, Paulo Gonçalves de Oliveira ${ }^{\mathrm{IV}}$
}

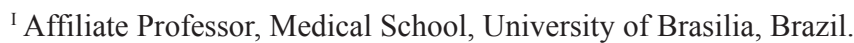

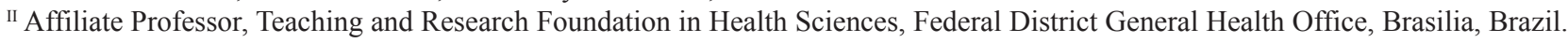

III Graduation student, Medical School, University of Brasilia, Brazil.

IV Associate Professor, Medical School, University of Brasilia, Brazil.

\begin{abstract}
Purpose: To evaluate the effects of infliximab, a murine/human chimeric monoclonal antibody, on the tensile strength of abdominal wall surgical wounds. Methods: Sixty Wistar healthy male rats with initial body weight between 215 and 390 g and 60 and 90 days of age were randomly assigned into two groups, E (Experimental) and C (Control) with 30 animals each. Group E animals received a single subcutaneous dose of $5 \mathrm{mg} / \mathrm{Kg}$ of infliximab, and Group $\mathrm{C}$ animals received equivalent subcutaneous volume of a solution of $0.9 \% \mathrm{NaCl}$. After $48 \mathrm{~h}$, animals from both groups were submitted to a $4 \mathrm{~cm}$ median incision in the abdominal wall, including all layers that had been reconstituted with continuous suture of the aponeurotic muscle and skin, with 5.0 nylon thread. Then, Group E animals were separated by simple allotment into three subgroups named E3, E7 and E14 with ten animals each, and those from group C into C3, C7, C14 and were submitted, respectively, the reoperation and euthanasia at the third, seventh and fourteenth postoperative day. The anterior abdominal wall, which was resected during reoperation, was cut with No 15 scalpel lamina perpendicularly to the surgical wound. Each specimen, in the form of a $6 \mathrm{~cm} \times 2 \mathrm{~cm}$ strip, was fixed by the extremity so that the suture line was equidistant from the fixation points of the dynamometer, in order to undergo the tensile strength test. The dynamometer, which was gauged for each series of measures, was calibrated to apply velocity to the $25 \mathrm{~mm} / \mathrm{min}$ rupture test; the rupture value was expressed in $\mathrm{N}$ (Newton). Prior to euthanasia, the abdominal vena cava was identified and punctured in order to collect blood for TNF- $\alpha$ dosage. Results: The mean tensile strength found for animals from subgroups E3, E7, E14, C3, C7, C14 were, respectively, 16.03, 18.69, 27.01, 28.40, 27.22, 29.15 and 24.30 N. In the results of the multiple comparisons tests, significant differences $(p<0.05)$ was found between subgroups E3 and E7 compared with C3, $\mathrm{C} 7$ and $\mathrm{C} 14$. Conclusion: The infliximab interfered in the healing of the abdominal wall wound decreasing the rupture strength in the inflammatory and proliferative phases.
\end{abstract}

Key words: Antibodies, Monoclonal. Abdominal Wall. Wound Healing. Rats.

\section{RESUMO}

Objetivo: Avaliar os efeitos do infliximabe, anticorpo monoclonal quimérico humano-murino, sobre a força tênsil da ferida operatória abdominal. Métodos: Sessenta ratos, linhagem Wistar, machos, sadios, com peso corporal inicial entre 215 e 390 g e 60 e 90 dias de vida foram distribuídos aleatoriamente em dois grupos, E (Experimental) e C (Controle) com 30 animais cada. Os animais do grupo E receberam por via subcutânea, dose única, de $5 \mathrm{mg} / \mathrm{Kg}$ de infliximabe, via subcutânea e os animais do grupo C receberam, volume equivalente, de solução de $\mathrm{NaCl}$ a $0,9 \%$, via subcutânea. Depois de $48 \mathrm{~h}$ os animais de ambos os grupos foram submetidos à incisão mediana na parede abdominal com $4 \mathrm{~cm}$ de extensão incluindo todos os planos que foram reconstituídos com sutura contínua músculo aponeurótica e pele, separadamente, com fio de nylon 5.0. A seguir os animais grupo E foram separados por sorteio simples em três subgrupos denominados E3, E7 e E14 com dez animais e os do grupo C em C3, C7 e C14 e foram submetidos, respectivamente, à reoperação e eutanásia no terceiro, sétimo e $14^{\circ}$ dia pós-operatório. A parede abdominal anterior, ressecada dos animais durante a reoperação, foi cortada, com lamina de bisturi $\mathrm{n}^{\circ} 15$, perpendicularmente à ferida operatória. Cada espécime, em forma de fita, com $6 \mathrm{~cm}$ por $2 \mathrm{~cm}$, foi preso pela extremidade de modo que a linha de sutura ficasse eqüidistante dos pontos de fixação do dinamômetro e realizado o teste de resistência tensil. O dinamômetro, aferido a cada série de medidas, foi calibrado para aplicar velocidade do teste de ruptura de $25 \mathrm{~mm} / \mathrm{min}$ e o valor de ruptura foi expresso em N (Newtons) Antes da eutanásia a veia cava abdominal foi identificada e puncionada para retirada de sangue para dosagem de TNF- $\alpha$. Resultados: A média da força tensil encontrada para os animais dos subgrupos E3, E7, E14, C3, C7 e C14 foram, respectivamente, 16,03; 18,69; 27,01; 28,40; 27,22; 29,15 e 24,30 N. Nos resultados dos testes de múltiplas comparações foram encontradas diferenças significantes $(p<0,05)$ entre os subgrupos E3 e E7 quando comparados com C3, C7e C14. Conclusão: O infliximabe interferiu na cicatrização da ferida da parede abdominal com diminuição da força de ruptura na fase inflamatória e proliferativa.

Descritores: Anitcorpos Monoclonais. Parede Abdominal. Cicatrização de Feridas. Ratos.

${ }^{1}$ Research performed at the Laboratory of Experimental Surgery, Medical School, University of Brasilia, Brazil. 


\section{Introduction}

Infliximab is an IgG1-class human/murine chimeric monoclonal antibody, which binds with affinity to soluble and transmembranal forms of TNF- $\alpha$, but not to lymphotoxin $(\mathrm{TNF}-\beta)^{1}$. Lnfliximab inhibits the functional activity of TNF- $\alpha$ in several types of in vitro bioassays ${ }^{2-3}$. In in vivo assays, infliximab quickly forms stable complexes with human TNF- $\alpha$, a process parallel to the loss of TNF- $\alpha$ bioactivity ${ }^{3-4}$.

Infliximab is effective in the induction and maintenance of the treatment of active Crohn's disease and the first biological component approved for its treatment, with limitations regarding the immunogenicity aspect. In some cases, the development of anti-infliximab antibodies, immediate or late hypersensitivity reactions and autoimmune phenomena caused by its murine fraction may occur, impairing its effectiveness or the continuity of the treatment ${ }^{5-6}$.

TNF- $\alpha$, produced by the endothelial cells and monocytes, is an inflammatory mediator, active in the in margination and cytotoxicity of polymorphonuclear cells, in the synthesis of collagen and it also provides metabolic substrate for the healing of wounds during the inflammatory phase ${ }^{1}$.

Although anomalous inflammation is unhealthy in arthritis, psoriasis and uveitis, it is important for the healing of wounds, and according to Carrico, "There is no healing without inflammation" 7 .

Drugs with anti-inflammatory activity, steroids or not, have aroused the interest of researchers, because of their potential interference in the healing process ${ }^{8-12}$.

Infliximab, used in the treatment of several diseases, reduces the pharmacological activity of TNF- $\alpha^{3-4}$ and because it is an inflammation and collagen deposition moderator, it may be assumed that the tensile strength of wounds is altered in animals treated with infliximab, similarly to what happens with diclofenac sodium $^{8,13}$ and other anti-inflammatory agents.

Clinical studies have reported impaired healing as an undesirable effect of infliximab ${ }^{1}$, but another study suggests better healing of chronic wounds with the topical use of infliximab ${ }^{14}$; however, no studies on the possible effects of infliximab on the tensile strength in the healing of wounds have been found.

\section{Methods}

This research was performed at the Laboratory of Experimental Surgery, Faculty of Medicine, University of Brasilia after the approval of the Ethics Committee on Animal Use (CEUA) of the Institute of Biological Sciences (ICB). The experimental surgical procedures were performed in accordance with ethical principles of the Brazilian College of Animal Experimentation (COBEA).

\section{Animal experimentation}

Sixty Wistar healthy male rats, Rattus norvegicus, with initial body weight between 215 and $390 \mathrm{~g}$ and 60 and 90 days of age, provided by the Laboratorio Bioagri Ltda., Planaltina, DF were randomly divided into two groups of 30 animals: experimental group (E) was treated with infliximab and control group (C) received placebo.

\section{Experimental design}

Group E animals received a single subcutaneous $5 \mathrm{mg} / \mathrm{Kg}$ dose of infliximab $48 \mathrm{~h}$ before the operation and group $\mathrm{C}$ animals received an equivalent dose of $0.9 \% \mathrm{NaCl}$. The drug (infliximab), presented in $100 \mathrm{mg}$ flask of lyophilized powder was dissolved in $10 \mathrm{ml}$ of distilled water ${ }^{1,6}$. Then, the solution was diluted in $90 \mathrm{ml}$ of $0.9 \% \mathrm{NaCl}$ solution, reaching a total volume of $100 \mathrm{ml}$.

Groups $\mathrm{E}$ and $\mathrm{C}$ were divided into six subgroups of ten animals each, named E3, E7 and E14 and C3, C7, C14, corresponding, respectively, to the $3^{\text {rd }}, 7^{\text {th }}$ and $14^{\text {th }}$ postoperative days, which would be submitted to reoperation and euthanasia. The distribution was random, performed by simple allotment without replacement, one by one, with six similar tags identified by acronyms E3, C3, E7, C7, E14 and C14.

The operations were performed 48 hours after the animals received the medication or placebo, after a preoperative fasting period of six hours. Anesthesia was performed with $10 \mathrm{mg} / \mathrm{kg}$ xylazine associated to $100 \mathrm{mg} / \mathrm{kg}$, ketamin, intramuscularly administered in the medial side of the right thigh of the animal ${ }^{15,16}$. The surgical instrument was cleaned, disinfected with a $2 \%$ glutaraldehyde solution before each operative session. The surgical procedures were performed by the same surgeon, using aseptic technique and obeying the following steps adopted by Oliveira ${ }^{17}$ : Immobilization of the animal on a wooden plate in dorsal position and fixation of its paws with adhesive tape, trichotomy of the anterior abdominal wall, asepsis of the abdominal skin with iodine-polyvinylpyrrolidone solution and alcohol at $70 \%$, intermediate $4 \mathrm{~cm}$ laparotomy at $1 \mathrm{~cm}$ from the genitalia.

Synthesis of the abdominal wall into two levels: the first with continuous simple suture including the peritoneum, muscle and aponeurosis in the intermediate line with 5-0 polypropylene suture, and the second with 5-0 polypropylene continuous suture using the Greek technique on the skin, performing a 6-0 polypropylene suture with a $1.5 \mathrm{~cm}$ cylindrical needle (Figure 1).

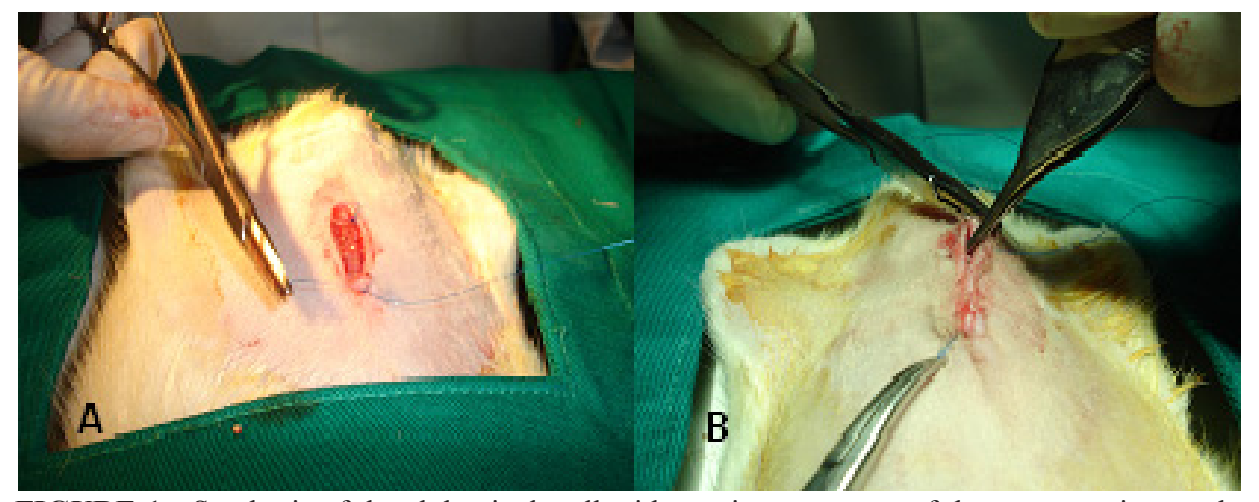

FIGURE 1 - Synthesis of the abdominal wall with continuous suture of the aponeurotic muscle with 6-0 polypropylene suture (A) and using the Greek technique with the same type of suture (B) 
In reoperations performed on the $3^{\text {rd }}, 7^{\text {th }}$ and $14^{\text {th }}$ postoperative days, a segment of $6 \mathrm{~cm} \times 4 \mathrm{~cm}$ of the anterior abdominal wall of each animal containing the surgical wound in its central portion was resected (Figure 2). Then, the abdominal vena cava was exposed and punctured and $1 \mathrm{ml}$ of blood was collected for TNF- $\alpha$ determination.

The segment of the abdominal wall was prepared for the removal of a $6 \mathrm{~cm} \times 2 \mathrm{~cm}$ strip (Figure 2) and which was fixed by its edges on the staffs of the force dynamometer with the line of suture equidistant from the fixation points. The rupture test rate was $25 \mathrm{~mm} / \mathrm{min}$ and the rupture value was expressed in Newton (N). The force dynamometer was gauged before each series of measures and the evaluation was performed through computerized analysis of the data obtained in a constant force tensiometer with tension capacity of $2,500 \mathrm{~N}$ in a vertical assay machine Versa Test (Mecmesin Versa ${ }^{\circledR}$ Test, United Kingdom) coupled with digital dynamometer AGF (Panambro Indústria Técnica S.A. SP).

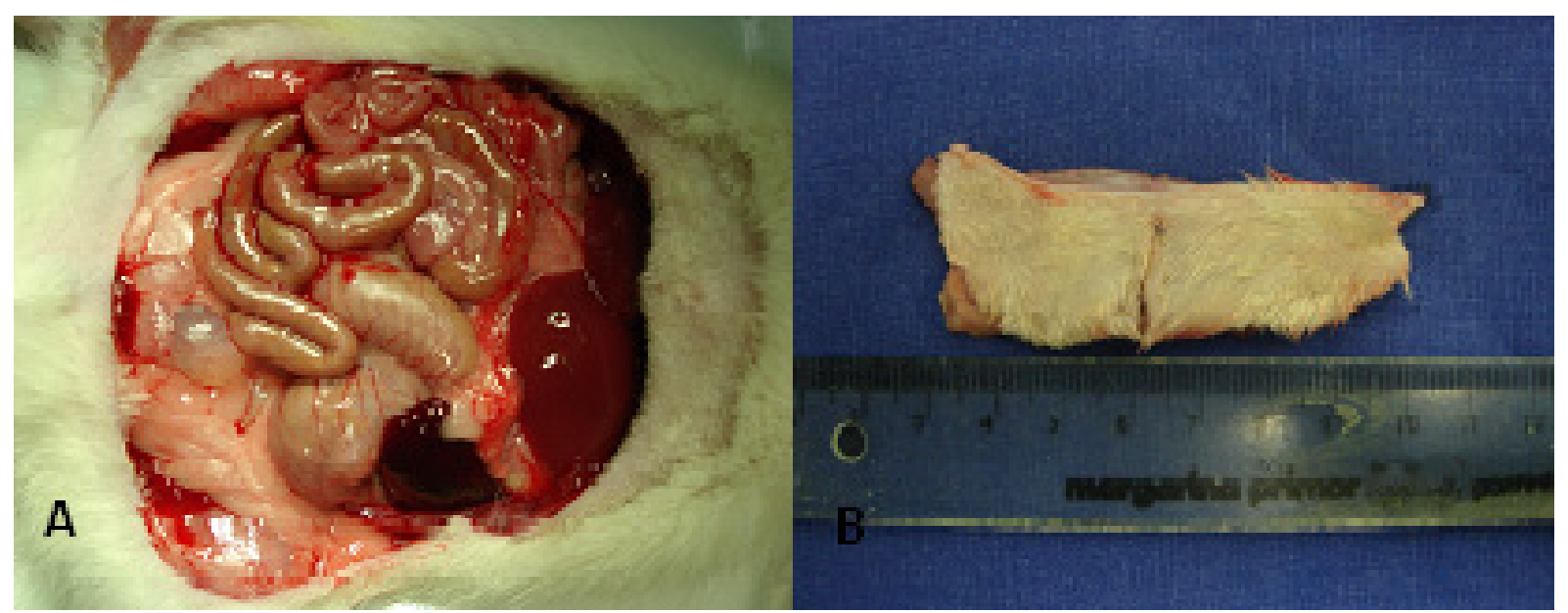

FIGURE 2 - The anterior abdominal wall containing the surgical wound was removed to the center (A) and the segment was prepared (B) to be fixed by its extremities in the dynamometer staffs

\section{TNF- $\alpha$ quantification}

One $\mathrm{ml}$ of blood, collected by puncture of the inferior vena cava, was placed in a microtube (Microtimer ${ }^{\mathrm{TM}}$ ) with gel for separation and was centrifuged for 5 minutes at $4000 \mathrm{rpm}$ at room temperature and the serum transferred to another microtube (Ependorf ${ }^{\mathrm{TM}}$ ) and stored at $-80^{\circ} \mathrm{C}$. The quantitative dosage of TNF- $\alpha$ in the serum of rats was performed through immunoenzymatic assay - Instant ELISA according to protocol adopted by Freitas ${ }^{18}$, using an ELISA Kit specific for rats (IBL® Immuno-Biological Laboratories Co. Ltd. Gumma, Japan).

A panel of randomized serum samples from apparently healthy rats was tested for TNF- $\alpha$, and a reference interval of values was obtained. The control samples were established from TNF- $\alpha$ concentrations of rats not submitted to surgical procedures. Standards and samples were run in the same test.

\section{Statistical analysis}

The results were submitted to statistical analysis for multiple comparisons, Tukey test, Mann-Whitney test and Student's t-test. The $\mathrm{p}<0.05$ values were considered significant.

\section{Results}

Four animals, one from the control group and three from the experimental group, died of undetermined causes, being excluded and not replaced.
The minimum dose of infliximab adjusted according to the weight of the animal was $1.10 \mathrm{mg}$ and the maximum dose was $1.95 \mathrm{mg}$ (standard deviation 0.22 , median 1.72). The average tensile strength found for animals in subgroups E3, E7, E14, C3, C7, C14 was $16.02,18.69,27.00,27.63,27.21,29.15 \mathrm{~N}$, respectively, where significant differences $(p<0.05)$ between the values obtained in subgroups E3, inflammatory phase, and E7, proliferative phase, when compared two by two with $\mathrm{C} 3$ and $\mathrm{C} 7$ were observed (Figure 3 and Table 1).

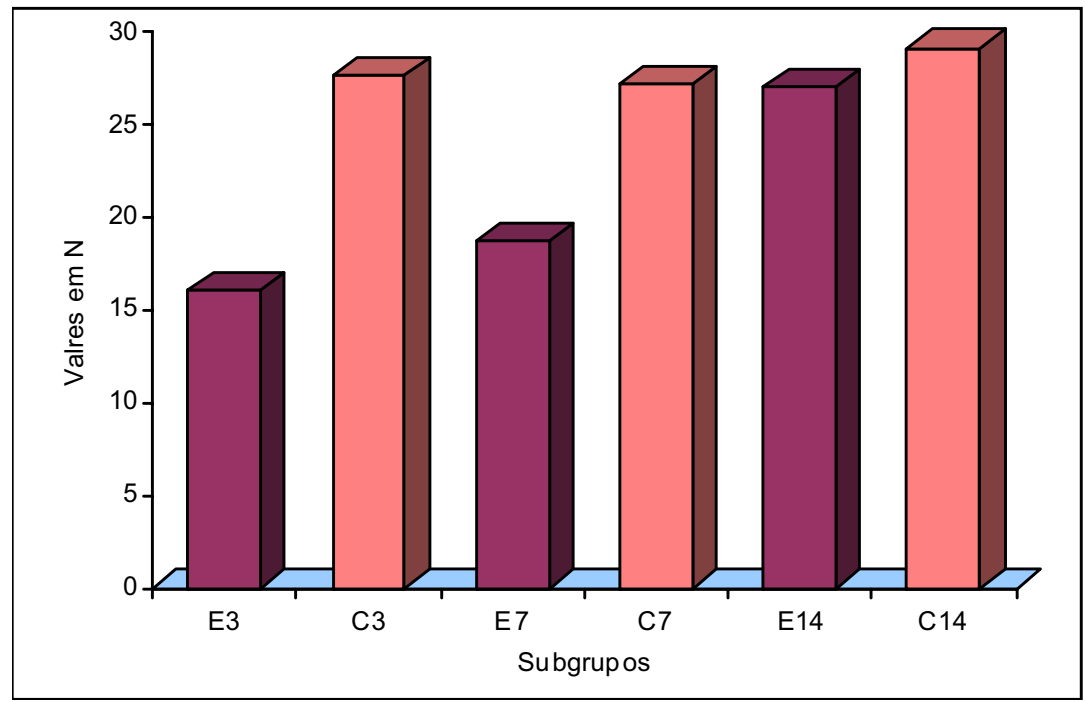

FIGURE 3 - Comparison of the tensile strength values in Newton obtained according to the experimental subgroup (E) composed of subgroups E3, E7, E14 and control group (C) composed of subgroups C3, C7 and C14 
TABLE 1 - Tensile rupture strength of the abdominal wall surgical wound in the experimental group (E) and in the control group (C)

\begin{tabular}{|c|c|c|c|c|c|c|c|c|}
\hline \multirow[b]{2}{*}{ Groups } & \multirow{2}{*}{$\mathrm{N}$} & \multirow{2}{*}{ Mean } & \multirow{2}{*}{$\begin{array}{l}\text { Standard } \\
\text { deviation }\end{array}$} & \multirow{2}{*}{$\begin{array}{l}\text { Standard } \\
\text { error }\end{array}$} & \multicolumn{2}{|c|}{$\begin{array}{l}\text { Confidence } \\
\text { Interval 95\% }\end{array}$} & \multirow[b]{2}{*}{ Maximum } & \multirow{2}{*}{ Minimum } \\
\hline & & & & & $\begin{array}{l}\text { Lower } \\
\text { limit }\end{array}$ & $\begin{array}{l}\text { Upper } \\
\text { limit }\end{array}$ & & \\
\hline E3 & 10 & 16.02 & 4.60 & 1.45 & 12.73 & 19.31 & 10.07 & 27.78 \\
\hline E7 & 9 & 18.69 & 4.69 & 1.56 & 15.08 & 22.29 & 14.23 & 30.29 \\
\hline E14 & 8 & 27.00 & 8.89 & 3.14 & 19.56 & 34.44 & 13.14 & 42.38 \\
\hline C3 & 10 & 27.63 & 7.20 & 2.27 & 22.48 & 32.79 & 18.57 & 38.42 \\
\hline C7 & 9 & 27.21 & 5.40 & 1.80 & 23.06 & 31.37 & 18.84 & 34.43 \\
\hline $\mathrm{C} 14$ & 10 & 29.15 & 7.25 & 2.29 & 23.95 & 34.34 & 20.56 & 40.22 \\
\hline
\end{tabular}

TNF- $\alpha$ values have not significantly changed with the surgical procedures except for subgroup E3, in which a significant decrease in the amount of TNF- $\alpha$ was observed, when compared with the other groups. When the TNF- $\alpha$ values of the experimental and control groups were compared with reference animals, it was observed that group E3 did not present an increased TNF- $\alpha$ production, as occurred with the other groups. Comparing the groups with equal postoperative time, a significant difference $(\mathrm{P}=0042)$ between groups $\mathrm{C} 3$ and $\mathrm{E} 3$ was found. No significant differences was observed for the other groups (Figure 4).

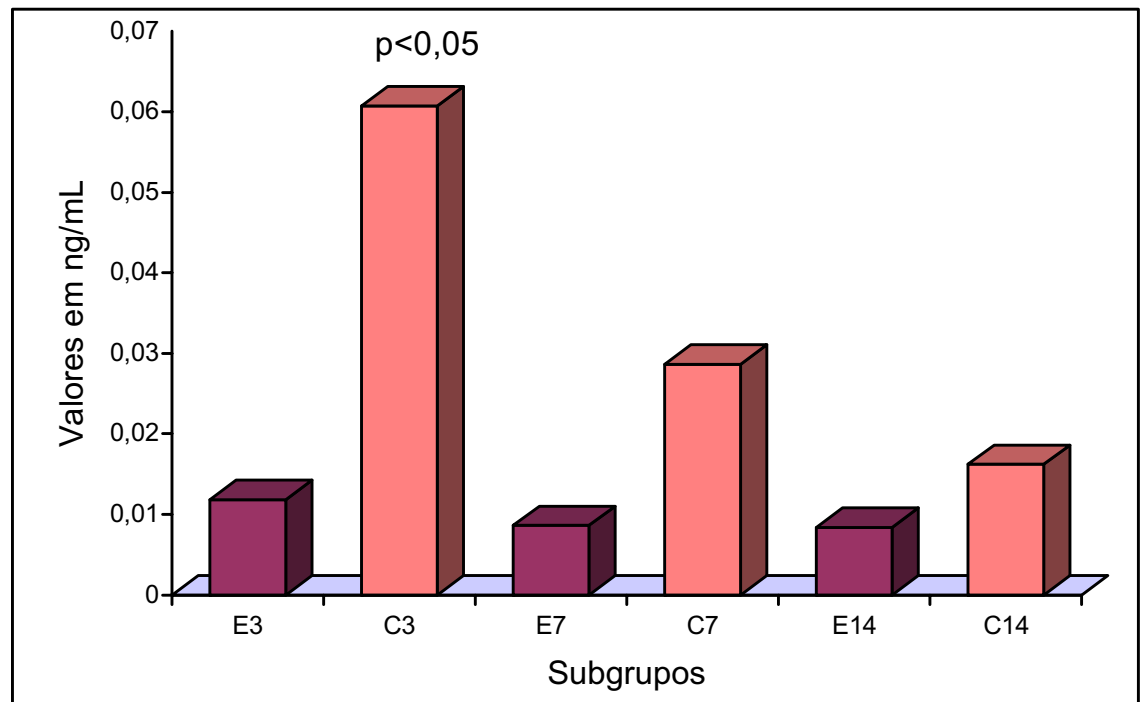

FIGURE 4 - TNF- $\alpha$ serum production in the experimental group (E3, E7 and E14) and in the control group (C3, C7 and $\mathrm{C} 14)$

In the analysis of the TNF- $\alpha$ levels and measured tensile strength, a moderate correlation was found $(r=0.4378)^{1}$, when the values were submitted to the Pearson test (Table 2)

TABLE 2 - TNF- $\alpha$ values in $\mathrm{ng} / \mathrm{ml}$ and tensile strength in $\mathrm{N}$ according to subgroups of animals treated with infliximab (E3, E7 and E17) and subgroups treated with placebo (C3, C7 and C14)

\begin{tabular}{lrrrrrr}
\hline & \multicolumn{1}{c}{ E3 } & \multicolumn{1}{c}{ E7 } & \multicolumn{1}{c}{ E14 } & \multicolumn{1}{c}{ C3 } & \multicolumn{1}{c}{ C7 } & \multicolumn{1}{c}{ C14 } \\
\hline TNF- $\alpha$ & 0,01177 & 0,008593 & 0,008359 & 0,06075 & 0,028605 & 0,01619 \\
Tensil & 16,02 & 18,69 & 27,01 & 27,63 & 27,21 & 29,15 \\
\hline
\end{tabular}

\footnotetext{
${ }^{1} \mathrm{r}=$ coefficient of Pearson
} 


\section{Discussion}

The method used in this experiment proved to be of easy implementation and reproduction. However, one of the aspects that deserve special attention is that the manufacture of segments to be tested must be similar in width and length and the placement of the specimen in the strength dynamometer must occur so that the suture line is equidistant from the fixation points ${ }^{19}$.

The four deaths that occurred among animals from both experimental and control groups, without replacement, did not impair the study; the data were submitted to statistical tests.

Since the dose of infliximab was proportional to the weight of the animal, it was considered that its effect on the tensile strength of the wound healing was not influenced by the difference in weight between animals.

A perfect healing depends on physiological events including inflammation, angiogenesis and collagen deposition with consequent wound contraction triggered by mediators such as TNF- $\alpha$. The suture dehiscences both of intestinal anastomosis and of surgical wound complications are involved in the genesis of infections and increased mortality and morbidity rates, hospital permanence and high costs; therefore, factors that inhibit the inflammatory mediators may have undesirable effects on the process of repairing and healing of wounds ${ }^{17,18,20}$.

Studies have reported that some drugs with antiinflammatory or pro-inflammatory action, including diclofenac sodium $^{8,13}$, misoprostol ${ }^{17}$, alter the wound healing, interfering with inflammation and collagen deposition.

On the $3^{\text {rd }}$ day, the control group presented a significant higher level of detection of TNF- $\alpha$, when compared to the experimental group. This result confirms that the drug was effective and therefore it was considered that possible effects of the administration of the drug would be related to the TNF- $\alpha$ inhibition.

This is consistent with the decrease in TNF- $\alpha$ levels in animals of the experimental group when compared to those of the control group with a significant difference between subgroups E3 and $\mathrm{C} 3$, what may explain the difference, also significant, of the tensile strength between the same subgroups, showing a relationship between the decrease on the tensile strength and TNF- $\alpha$ levels found in this study in relation to the inflammatory stage of healing. In the late stage of healing, collagen remodeling, and no influence on the abdominal wall wound healing was observed, unlike the results obtained by Freitas ${ }^{18}$ in a study on colonic anastomoses.

Infliximab is a potent TNF- $\alpha$ inhibitor that has, in addition to other indications, therapeutic action on Crohn's disease $^{21}$, juvenile idiopathic arthritis ${ }^{22}$ and Behçet's disease ${ }^{23}$, however, changes on the healing tensile strength are not among the undesired effects.

In this study, results have shown the occurrence of significant decrease on the wound healing tensile strength in animals treated with infliximab submitted to euthanasia on the $3^{\text {rd }}$ and $7^{\text {th }}$ post-operative days, contrary to what occurred with diclofenac sodium ${ }^{13}$, which caused a decreased in the rupture strength on the $7^{\text {th }}$ and $14^{\text {th }}$ days.

On the other hand, in chronic wounds ${ }^{14}$, proctitis $^{24}$ and skin fistulas ${ }^{21}$, infliximab presents favorable healing action, contrary to what occurred in this study with surgical wounds in which healing by first intention was expected.

Similar studies measuring the tensile strength of colic anastomoses in rats treated with infliximab ${ }^{17}$ have reported results similar to the present study.

\section{Conclusion}

The infliximab interfered in the healing of abdominal wall wound of rats with decreased rupture strength in the inflammatory and proliferative phases.

\section{References}

1. Brasil. Ministério da Saúde. Agência Nacional de Vigilância Sanitária. Infliximabe. In: Compêndio de Bulas de Medicamentos. Brasília: Ed. ANVISA; 2004/2005.p.2330-44.

2. Knight DM, Trinh H, Le J, Siegel S, Shealy D, McDonough M, Scallon B, Moore MA, Vilcek J, Daddona P, et al. Construction and initial characterization of a mouse-human chimeric anti-TNF antibody. Mol Immunol. 1993;30(16):1443-53.

3. Siegel SA, Shealy DJ, Nakada MT, Le J, Woulfe DS, Probert L, Kollias G, Ghrayeb J, Vilcek Daddona PE. The mouse/human chimeric monoclonal antibody $\mathrm{Ca} 2$ neutralizes TNF in vitro and protects transgenic mice From cachexia and TNF lethality in vivo. Cytokine. 1995; 7 (1):15-25. 4. Scallon BJ, Moore MA, Trinh H, Knight DM, Ghrayeb J. Chimeric anti-TNF-Alpha monoclonal antibody $\mathrm{Ca} 2$ binds recombinant transmembrane TNF-Alpha and activates immune effector functions. Cytokine. 1995; 7(3):251-9.

5. Sandborn WJ. Optmizing anti-tumor necrosis factor strategies in inflamatory bowel disease. Curr Gastroenterol Rep. 2003;5(6):501-5.

6. Danese S, Semeraro, S, Armuzzi A, Papa A, Gasbarrini A. Biological therapies for inflammatory bowel disease: research drives clinics. Mini Rev Med Chem. 2006;6(7):771-84.

7. Carrico TJ, Mehrhof AI, Cohen IK. Biology of wound healing. Surg Clin North Am. 1984;64:721-32.

8. Sousa JB, Soares EG, Aprilli F. Effects of diclofenac sodium on intestinal anastomotic healing: experimental study on the small intestine of rabbits. Dis Colon Rectum. 1991;34(7):613-7.

9. Eubanks TR, Greenberg JJ, Dobrin PB, Harford FJ, Gamelli RL. The effect of different corticosteroids on the healing colon anastomosis and cecum in a rat model. Am Surg. 1997;63:266-9.

10. Sirimarco MT. Estudo comparativo dos efeitos de dois corticosteróides sintéticos, deflazacort e predinisona, na cicatrização de anastomoses colônicas de ratos [Doutorado]. Universidade de São Paulo: Faculdade de Medicina de Ribeirão Preto; 2000.

11. Gogia, PP. Clinical wound management. USA: Slack Incorporated; 1995.

12. Mantzoros I, Kanellos I, Angelopoulos S, Koliakos G, Pramateftakis, MG, Kanellos D, Zacharakis E, Zaraboukas T, Betsis D. The effect of insulin-like growth factor I on healing of colonic anastomoses in cortisone-treated rats. Dis Colon Rectum. 2006;49(9):1431-8.

13. Minossi JG, Leite CVS, Naresse LE, Rodrigues MAM, Angeleli AYO, Kobayasi S. Sodium diclofenac effect in abdominal wound healing in rats: histological, breaking strength e tissue collagen studies. Acta Cir Bras. 2001;16(3):146-54.

14. Streit M, Beleznay Z, Braathen LR. Topical application of tumor necrosis factor-alpha antibody infliximab improves healing of chronic wounds. Int Wound J. 2006;3(3):171-9.

15. Mezadri TJ, Tomáz VA, Amaral VLL. Animais de laboratório: cuidados na iniciação experimental. Santa Catarina: Editora da UFSC; 2004.

16. Lopes JV, Oliveira PG, Sousa JB, Báo SN, Takano GHS, Leal IIR. Histopathologic evaluation of the peritoneum exposed to heat shock: experimental study in rats. Acta Cir Bras. 2007;22(5):342-50. Available from URL: http://www.scielo.br/acb 
17.Oliveira PG, Soares EG, Aprilli F. Infuence of misoprostol, a synthetic prostaglandin $\mathrm{E}_{1}$ analog, on the healing of colonic anastomoses in rats. Dis Colon Rectum. 1994;37(7):660-3.

18. Freitas LAM. Avaliação dos efeitos do anticorpo monoclonal, infliximabe, na cicatrização de anastomoses colônicas: estudo experimental em ratos. [Mestrado]. Brasília: Universidade de Brasília, Faculdade de Medicina; 2007.

19. Rossi LF, Ramos RR, Ely JB, Kestering DM, Soldi MS, Brum SPB, d'Acampora AJ. Considerations that may infl uence the result of trials assessing tensile strength in experimental surgery. Acta Cir Bras. 2007;22(6):73-7.

20. Oliveira PG, Sousa JB, Reys LGCV, Magalhães AV, Rabelo FS, Muniz $\mathrm{KC}$. Effects of enoxaparin on the healing of abdominal wall in rats: study on breaking strength and histopatology. Acta Cir Bras. 2006;21(4):247-51. Available from URL: http://www.scielo.br/acb
21. Gonçalves CG, Coelho JCU, Amarante HMBS. Obstrução intestinal após uso de infliximabe no tratamento de fístula êntero-cutânea na doença de Crohn. Rev Col Bras Cir. 2005;32(4):223-4.

22. Martin P, Medeiros AC, Goldennstein-Schainberg C. The role of tumor necrois factor inhibitors in the treatment of junvenile idiopatic arthritis. Rev Bras Reumatol. 2006;46(2):126-33.

23. Souza AWS, Pileggi P, Hachbarth ET. Tratamento com infliximabe da doença de Behçet ativa. Rev Bras Reumatol. 2005;45(2):91-3.

24. van der Hagen SJ, Baeten CG, Soeters PB, Russel MG, Beets-Tan RG van Gemert WG. Anti-TNF-alpha (infliximab) used as induction treatment in case of active proctitis in a multistep strategy followed by definite surgery of complex anal fistulas in Crohn's disease: a preliminary report. Dis Colon Rectum. 2005;48(4):758-67.

Conflict of interest: none

Financial source: none

\author{
Correspondence: \\ João Vieira Lopes \\ SQN 202, B1 C/203 \\ 70832-030 Brasilia-DF Brazil \\ joaolopes@unb.br
}

Received: March 19, 2008

Review: May 21, 2008

Accepted: June 18, 2008

\title{
How to cite this article
}

Lopes JV, Freitas LAM, Marques RD, Bocca AL, Sousa JB, Oliveira PG. Analysis of the tensile strength on the healing of the abdominal wall of rats treated with infliximab. Acta Cir Bras. [serial on the Internet] 2008 Sept-Oct;23(5). Available from URL: http://www.scielo.br/acb

*Color figures available from www.scielo.br/acb 